\title{
Endodontic treatment of single rooted maxillary central incisor with two canals: A case report
}

\author{
Gufran Ali Syed ${ }^{1}$, Sanjyot Mulay ${ }^{2}$, Suruchi Sisodia $^{3}$, Hina Gufran Syed ${ }^{4}$ \\ ${ }^{1}$ Reader, Department of Conservative Dentistry and Endodontics, Modern Dental College \& Research Centre, \\ Indore, Madhya Pradesh, INDIA. \\ ${ }^{2}$ Professor \& Guide, Department of Conservative Dentistry and Endodontics, Dr. D Y Patil Dental College \\ \&Hospital, Pune, Maharashtra, INDIA. \\ ${ }^{3}$ Senior Lecturer, Department of Conservative Dentistry and Endodontics, Modern Dental College \& Research \\ Centre, Indore, Madhya Pradesh, INDIA. \\ ${ }^{4}$ Private practitioner, Smile Dental Clinic, Near Lady Halima Hospital, Khajrana, Indore, Madhya Pradesh, \\ INDIA.
}

\begin{abstract}
:
Introduction: The success of endodontic therapy requires a knowledge of the internal and external dental anatomy and its variations in presentation. Abnormal morphology of the root canal may exist in any tooth even a maxillary central incisor. Knowledge of anatomic variations aid in preventing treatment failures.

Case Report: This case report presents non-surgical endodontic treatment of maxillary central incisor with two canals.

Conclusion: Clinician should be careful that even the most routine of cases might deviate from the usual.

Keywords: maxillary central incisor; unusual anatomy; two canals
\end{abstract}

\section{Introduction}

Variation in the number of roots or in canal configuration may impact endodontic treatment. Thus, indepth knowledge of the morphological variations of root/canal is must for the success of any endodontic procedure [1].

It has been documented in several studies that in $100 \%$ of the cases, maxillary central incisors had one root and one canal $(2,3,4,1,5,6,7)$. The presence of an additional root/ canal in maxillary central incisors is rare but lateral canals are common [8]. However, $3 \%$ of maxillary central incisors have been reported with two separate and distinct root canals [9].

The purpose of this article is to present a case report of maxillary central incisor with two canals.

\section{Case Report}

A 46 year old male in good health was referred to our private practice for endodontic treatment of left maxillary central incisor (Tooth No. 21). Clinical examination revealed, fractured pin retained Class-4 composite restoration with 21 . The tooth 21 was darker in color than the adjacent teeth. Tooth 21 did not respond to thermal and electrical vitality tests, palpation and percussion. Radiographic evaluation revealed complete obliteration of root canal space (calcific metamorphosis) (Figure 1). However, this does not confirm the absence of pulp/ canal space clinically. Based on the above examinations and tests, nonsurgical endodontic treatment of tooth 21 was planned.

The tooth 21 was anesthetized and isolated with rubber dam; dental floss and wooden wedges were used to stabilize rubber dam. Access opening was done using high speed round diamond point (Mani, Japan). The canals were explored (a buccal and a palatal one). The working length, of both the canals, were determined radiographically (Figure 2) and also by using Root ZX electronic apex locator (J Morita Corp., Kyoto, Japan). The root canals were cleaned and shaped using \#1, \#2 and \#3 Gates-Glidden drills (Dentsply, Maillefer, Switzerland) and hand instruments (K file, Mani, Japan) with passive step-back technique. The buccal canal was instrumented to master file size of 60 and palatal canal to size of 40 . The root canals were copiously irrigated with $2.5 \%$ sodium hypochlorite solution. After drying with paper points, calcium hydroxide (Meta Biomed Co. Ltd., Korea) was then placed as an intracanal medicament and sealed coronally with cavit (ESPE, Germany). After one week, canals were filled using lateral condensation with gutta-percha points and AH plus sealer (Dentsply, Germany) (Figure 3). In the same appointment pre-fabricated post was placed and composite core was built-up. Impression was taken and after 2 days porcelain fused to metal crown was cemented using dual cure resin cement. 


\section{Discussion}

It is extremely uncommon to have aberrant canal morphology in maxillary central incisor. However, some cases have been reported in the literature with dramatical variations in the root canal anatomy. When encountered, such unusual morphology may complicate conventional treatment [1].

In the present case, we noted the uncommon root canal anatomy of maxillary central incisor with one root and two canals, without morphological anomaly of the crown. The pulp was also greatly obliterated (Figure1), the extended shank round bur in a miniature handpiece was used to extend the depth of cut to find a thin orifice. Repeated radiographs were taken to verify the depth and direction of the cut. In order to achieve complete control over the direction and motion of the instrument occlusal opening must be enlarged.

Disturbances during morpho-differentiation of tooth germs are rare in the permanent dentition. However, there are a few case reports describing endodontic treatment of such teeth in the literature. In the present case the size and shape of maxillary central incisor appears to be normal. Therefore, there are no chances of any condition, like fusion, germination, dens in dente, palate-gingival or disto-lingual groove.

Sabala et al [10] reported that aberrations occurring less than $1 \%$ of the time were $90 \%$ bilateral. However, $88.9 \%$ of the case reports of maxillary central incisors with two roots/ two canals, we reviewed were unilateral. Incidence of maxillary central incisors with two roots/ two canals is more common in females $(72.7 \%)$ and in $72.7 \%$ of the cases it is found on the right side. Also, the cases we reviewed with two roots/ two canals, the root canals were located mesio-distally in $46.1 \%$ cases and bucco-palatally in $38.4 \%$ cases. Among all the cases, only $23.5 \%$ of the maxillary central incisor with more than one canals are single-rooted and only $11.7 \%$ cases has three canals (table 1 ).

Thus, aberrant root canal anatomy can be found even in the normal appearing crown and radiograph. Therefore, in order to locate extra root/ canal certain points should be followed -

1. Cautious interpretation of radiograph [5].

2. Take more than one radiograph at different angulations. With one radiograph correct endodontic diagnosis was obtained only $74 \%$ of the time and with three radiographs taken at different angulations it was increased to 90\%.[5].

3. The use of electronic apex locator is recommended for working length determination to avoid mistakes that might occur as a result of superimposition of files in root with multiple canals [9].

4. An endodontic microscope should be used to examine the pulp chamber, including the walls and the floor, as well as the root canals to detect access openings of additional root canals that might not be found easily [9].

5. The absence of mobility in the presence of a remarkable probing depth could be due to the presence of an extra root [4].

\section{Conclusion}

For successful endodontic treatment dentist should have good knowledge of all possible root canal anatomical configurations, so as to remove entire necrotic tissue and toxic products from root canal system. Keep in mind, no aspect of clinical endodontics is more important in locating aberrant anatomy than the Ability, Attitude and Desireof the clinician.

\section{References}

[1]. Plata RG, Plata WG. Conventional and surgical treatment of a two-rooted maxillary central incisor. J Endod 2003;29:422-24.

[2]. Weine FS. Endodontic Therapy. 4th Ed. St. Louis, Mosby;1989:245-251.

[3]. Ingle JI, Backland LK. Endodontics. 4th Ed. Baltimore, Williams and Wilkins;1994:92-227.

[4]. Genovese FR, Marsico EM. Maxillary central incisor with two roots: A case report. J Endod 2003;29:220-21.

[5]. Lin WC, Yang SF, Pai SF. Nonsurgical endodontic treatment of a two rooted maxillary central incisor. J Endod 2006;32:478-481.

[6]. Nezami MS, Mokhber N. Endodontic treatment of a maxillary central incisor with three root canals. J Oral Sci 2007;49:245-47.

[7]. Rodrigues EA, Silva SJA. A case of unusual Anatomy: Maxillary central incisor with two root canals. Int J Morph 2009;27:827-30.

[8]. Vertucci FJ, Haddix JE, Britto LR. Pathways of the pulp. 9th Ed. St. Louis, Mosby;2006:148-232.

[9]. Gondim E, Setzer F, Zingg P, Karabucak B. A maxillary central incisor with three root canals: A case report. J Endod 2009;35:1445-47.

[10]. Sabala CL, Benenati FW, Neas BR. Bilateral root or root canal aberrations in a dentalschool patient population. J Endod 1994;20:38-42.

[11]. Emmanuel, Indira R, Kandaswamy D. Maxillary incisor with two roots - A case report. J Cons Dent 2007;10:74-6.

[12]. Cimilli H, Kartal N. Endodontic treatment of unusual central incisors. J Endod 2002;28:480-81.

[13]. Patterson JM. Bifurcated root of upper central incisor. Oral Surg Oral Med Oral Pathol 1970;29:222

[14]. Heling B. A two rooted maxillary central incisor. Oral Surg Oral Med Oral Pathol 1977;43:649.

[15]. Mader CL, Konzelman JL. Double-rooted maxillary central incisor. Oral Surg Oral Med Oral Pathol 1980;50:99.

[16]. Sinai IH, Lustbader S. A dual-rooted maxillary central incisor. J Endod 1984;10:105-6.

[17]. Michanowicz AE, Michanowicz JP, Ardila J, Posada A. Apical surgery on a two-rooted maxillary central incisor. J Endod 1990;16:454-5.

[18]. Nazhan SA. Two root canals in a maxillary central incisor with enamel hypoplasia. J Endod 1991;17:469-71

[19]. Lambruschini GM, Camps J. A two-rooted maxillary central incisor with a normal clinical crown. J Endod 1993;19:95-6.

[20]. Khojastehpour L, Khayat A. Maxillary central incisor with two roots: A case report. J Dent 2005;2:74-77. 
[21]. Sponchiado EC, Ismail HAA, Braga MRL, Carvalho FK, Simoes CACG. Maxillary central incisor with two root canals: A case report. J Endod 2006;32:1002-04.

[22]. Shokouhinejad N, Sheykhrezaee MS, Assadian H. Endodontic treatment of two canalled maxillary central and lateral incisors: A case report. Int Endod J 2009;4:79-80.

Tables

Table 1: Summary of case reports of the maxillary central incisor with more than one root/ one canal.

* - Possible gemination

Figure

\begin{tabular}{|c|c|c|c|c|c|c|c|}
\hline Authors & Year & Side & ex & $\begin{array}{l}\text { Bilateral or } \\
\text { unilateral }\end{array}$ & $\begin{array}{l}\text { Number } \\
\text { of root/ } \\
\text { canals }\end{array}$ & $\begin{array}{l}\text { Location of } \\
\text { canals }\end{array}$ & Treatment \\
\hline Patterson (13) & 1970 & $F$ & & Unilateral & $2 / 2$ & - & None \\
\hline Heling (14) & 1977 & 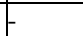 & & Unilateral & $2 / 2$ & - & None \\
\hline Mader\&Konzelman (15) & 1980 & 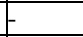 & & Unilateral & $2 / 2$ & - & None \\
\hline Sinai \&Lustbader (16) & 1984 & - & & Unilateral & $2 / 2$ & - & Apexogenesis \\
\hline Michanowicz et al (17)* & 1990 & - & & Unilateral & $2 / 2$ & $\begin{array}{l}1 \text { Mesial } \\
1 \text { Distal }\end{array}$ & Surgery \\
\hline Nazhan (18) & 1991 & Right & & $\begin{array}{l}\text { Not } \\
\text { mentioned }\end{array}$ & $1 / 2$ & $\begin{array}{l}\text { 1 Mesial } \\
1 \text { Distal } \\
\end{array}$ & $\begin{array}{l}\text { Conventional } \\
\text { RCT }\end{array}$ \\
\hline $\begin{array}{ll}\text { Lambruschini\& } & \text { Camps } \\
\text { (19) } & \end{array}$ & 1993 & & & $\begin{array}{l}\text { Not } \\
\text { mentioned }\end{array}$ & $2 / 2$ & $\begin{array}{l}\text { 1 Mesial } \\
1 \text { Distal }\end{array}$ & $\begin{array}{l}\text { Conventional } \\
\text { RCT }\end{array}$ \\
\hline Genovese \&Marsico (4) & 2003 & Right & & $\begin{array}{l}\text { Not } \\
\text { mentioned }\end{array}$ & $2 / 2$ & $\begin{array}{l}\text { 1 Buccal } \\
1 \text { Palatal }\end{array}$ & $\begin{array}{l}\text { Conventional } \\
\text { RCT }+ \text { Surgery }\end{array}$ \\
\hline Plata \& Plata (1) & 2003 & Right & & $\begin{array}{l}\text { Not } \\
\text { mentioned }\end{array}$ & $2 / 2$ & $\begin{array}{l}1 \text { Mesial } \\
1 \text { Distal }\end{array}$ & $\begin{array}{l}\text { Conventional } \\
\text { RCT + Surgery }\end{array}$ \\
\hline $\begin{array}{l}\text { Khojastehpour\&Khayat } \\
(20)\end{array}$ & 2005 & Right & & Unilateral & $2 / 2$ & $\begin{array}{l}1 \text { Mesial } \\
1 \text { Distal }\end{array}$ & $\begin{array}{l}\text { Conventional } \\
\text { RCT }\end{array}$ \\
\hline Sponchiado et al (21) & 2006 & Right & & Unilateral & $2 / 2$ & $\begin{array}{l}1 \text { Mesial } \\
1 \text { Distal }\end{array}$ & $\begin{array}{l}\text { Conventional } \\
\text { RCT }\end{array}$ \\
\hline Lin et al (5) & 2006 & Left & & Unknown & $2 / 2$ & $\begin{array}{l}\text { 1 Buccal } \\
1 \text { Palatal }\end{array}$ & $\begin{array}{l}\text { Conventional } \\
\text { RCT }\end{array}$ \\
\hline Nezami\&Mokhber (6) & 2007 & Right & & Bilateral & $1 / 3$ & $\begin{array}{l}1 \mathrm{MB} \\
1 \mathrm{DB} \\
1 \text { Palatal }\end{array}$ & $\begin{array}{l}\text { Conventional } \\
\text { RCT }\end{array}$ \\
\hline Shokouhinejad et al (22) & 2009 & Right & & $\begin{array}{l}\text { Not } \\
\text { mentioned }\end{array}$ & $2 / 2$ & $\begin{array}{l}\text { 1 Buccal } \\
\text { 1 Palatal } \\
\end{array}$ & $\begin{array}{l}\text { Conventional } \\
\text { RCT }\end{array}$ \\
\hline Rodrigues \& Silva (7) & 2009 & Left & & Unknown & $1 / 2$ & $\begin{array}{l}\text { 1 Buccal } \\
1 \text { Palatal } \\
\end{array}$ & $\begin{array}{l}\text { Conventional } \\
\text { RCT }\end{array}$ \\
\hline Gondim et al (9) & 2009 & Right & & $\begin{array}{l}\text { Not } \\
\text { mentioned }\end{array}$ & $2 / 3$ & $\begin{array}{l}1 \mathrm{MB} \\
1 \mathrm{DB} \\
1 \text { Palatal }\end{array}$ & $\begin{array}{l}\text { Conventional } \\
\text { RCT }\end{array}$ \\
\hline Present case & 2011 & Left & & Unilateral & $1 / 2$ & $\begin{array}{l}1 \text { Buccal } \\
1 \text { Palatal }\end{array}$ & $\begin{array}{l}\text { Conventional } \\
\text { RCT }\end{array}$ \\
\hline
\end{tabular}

\section{Legends}

Figure 1: Preoperative IOPA.

Figure 2: Working length determination IOPA.

Figure 3: Post obturation IOPA.

\section{Figures}

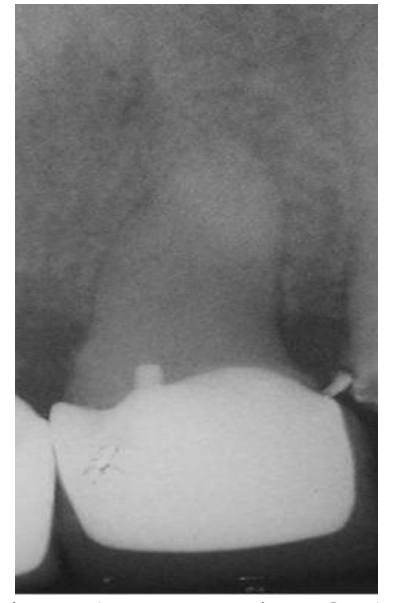

Figure 1: Preoperative IOPA. 


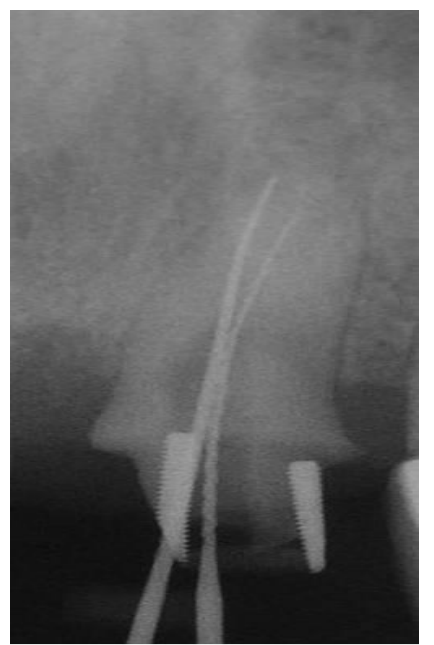

Figure 2: Working length determination IOPA.

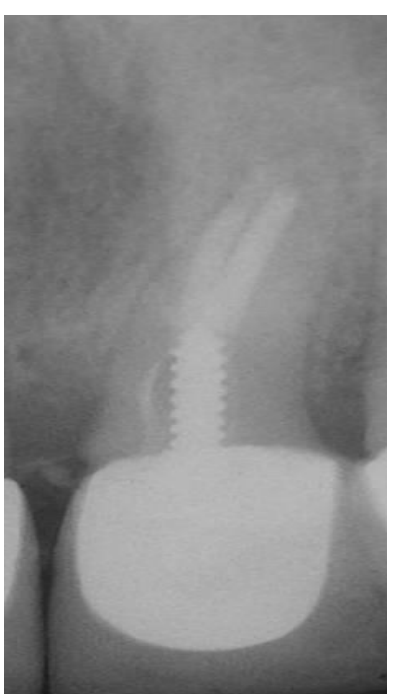

Figure 3: Post obturation IOPA. 